\title{
An assessment of flux of radionuclide contamination through the large Siberian rivers to the Kara Sea
}

\author{
V. Maderich ${ }^{1}$, N. Dziuba ${ }^{1}$, V. Koshebutsky ${ }^{1}$, M. Zheleznyak ${ }^{1}$ and V. Volkov ${ }^{2}$ \\ ${ }^{1}$ Institute of Mathematical Machine and System problems, Glushkov Av. 42, \\ 03187 Kiev, Ukraine \\ ${ }^{2}$ Nansen International Environmental and Remote Sensing Center, 26/28, Bolshaya \\ Monetnaya Str., 197101 St. Petersburg, Russia
}

\begin{abstract}
A linked chain of 1D river model RIVTOX and 3D estuary model THREETOX was used to assess impact of the previous and potential releases from the nuclear installations in the basins of Ob' and Yenisey rivers on radioactive contamination of the rivers and the Kara Sea. The RIVTOX includes the model of river hydraulics, suspended sediment and radionuclide transport in river channels. THREETOX includes a set of sub-models: a hydrodynamics sub-model, ice dynamics-thermodynamics sub-model, suspended sediment transport and radionuclide transport sub-models. The radionuclide transport model simulates processes in the water, suspended sediments and in bottom sediments. The simulations of the flux of ${ }^{90} \mathrm{Sr}$ and ${ }^{137} \mathrm{Cs}$ through the Ob' River and estuary from activities at the Mayak Production Association for the period 1949-1994 and through the Yenisey River and estuary from activities at the Mining, Chemical Combine for the period 1959-1994 were carried out. Based on scenarios, simulations have been performed in order to assess the potential risk of contamination from existing and potential sources of radionuclides into the Kara Sea through the Ob’ and Yenisey rivers.
\end{abstract}

\section{INTRODUCTION}

The activities of several nuclear reprocessing plants (Siberian Chemical Combine (SCC), Mining, Chemical Combine (MCC) and Mayak Production Association (Mayak)) that are placed on the watersheds of large Siberian rivers Ob' and Yenisey may potentially cause contamination of the Arctic Ocean. The using of the model tools is necessary to assess the influence on potential radioactivity spreading from these sources and impact of global warming on transport and fate of radionuclides. In frame of EU INCO-COPERNICUS project RADARC [1] a Generic Model System (GMS) was developed as a new tool for such assessment. In GMS three types of models are integrated and merged: for simulation of transport of radionuclides from terrestrial sources through the $\mathrm{Ob}$ ' and Yenisey rivers, for the Kara Sea and the entire Arctic Ocean. The river model is a linked chain of 1D river model and 3D model of stratified estuary. This paper describes chain of river-estuary models and presents results of the simulations of the flux of ${ }^{90} \mathrm{Sr}$ and ${ }^{137} \mathrm{Cs}$ through the Ob' River from activities at the Mayak for the period 1949-1994 and through the Yenisey River from activities at the MCC for the period 1959-1994. Based on scenarios, simulations have been performed in order to assess the risk of contamination of Arctic Ocean by potential releases from the nuclear installations in the basins of the Ob' and Yenisey rivers. 


\section{CHAIN OF RIVER-ESTUARY MODELS}

\subsection{RIVTOX model}

The one-dimensional river model RIVTOX (Zheleznyak et al. [2]) simulates the radionuclide and chemical pollution transport in networks of river channels. Sources can be a direct release into the river or the runoff from the catchment. The hydraulics part of the RIVTOX is based on the of Saint-Venant equations. The governing equations of the sub-model of suspended sediment and radionuclide transport model are derived from the 3-D model equations. They describe advection-diffusion transport of the cross-sectional averaged concentrations of suspended sediments, radionuclide in solution, radionuclide in suspended sediments and in bottom deposits. The adsorption-desorption and diffusion contamination transfer in the systems "solute - suspended sediments" and "solute - bottom deposition" are treated also via the distribution coefficient approach.

\subsection{THREETOX model}

The THREETOX code (Margvelashvili et al. [3]) is intended for simulation of the transport and fate of the radionuclides and other contaminants in the stratified waterbodies. THREETOX includes a set of sub-models: a hydrodynamics sub-model, ice dynamics-thermodynamics sub-model, suspended sediment transport and radionuclide transport sub-models. The hydrodynamics is simulated on the basis of the three-dimensional, time-dependent, free surface, primitive equation model. The $k-\varepsilon$ turbulence model is used. The dynamic-thermodynamic ice and snow model is based on the modified Hibler approach. Suspended sediment transport is described by the advection-diffusion equations, taking into account fall velocities of the sediment grains. The bottom boundary condition describes sediment resuspension or settling down depending on the ratio between the equilibrium and actual near bottom suspended sediment concentration. The thickness of the upper layer of the bottom deposition is governed by the equation of the bottom deformation. The equations of the radionuclide transport describe the concentration of the radionuclide in solute, in the suspended sediments and the concentration in the bottom deposition. The exchanges between these forms have been described as adsorption-desorption and sedimentation-resuspension processes. Adsorption and desorption of radionuclide between liquid and solid phases are described by the radionuclide exchange rates between suspended sediment and water $a_{12}^{w}$, bottom sediment and water $a_{12}^{b}$, and by the distribution coefficients "solute - suspended sediments" $K_{d}^{w}$, solute - bottom deposition" $K_{d}^{b}$, respectively.

\section{STUDY AREAS AND MODEL SETUP}

Pathway of radionuclides from Mayak site to the Kara Sea (Fig. 1) includes Techa River (184 km), Iset River (359 km), Tobol River (426 km), Irtysh River (636 km), Ob’ River (1000 km) and Ob’ Bay $(750 \mathrm{~km})$. The SCC is located along Romashka River which is tributary of Tom River $(75 \mathrm{~km})$ that discharges into the Ob' River (2273 km from the delta). The MCC is placed on the bank of the Yenisey River at distance $2400 \mathrm{~km}$ on the river delta. Yenisey Gulf is around $300 \mathrm{~km}$ length. According hydrologic classification both rivers are considered to be a rivers with spring-summer flood, therefore radionuclide transport strongly varies over the year. The median value of suspended sediment size in the lower Ob' and Yenisey rivers in August is $0.08 \mathrm{~mm}$ and $9.5 \mathrm{~mm}$, respectively, whereas at spring they are $0.03 \mathrm{~mm}$ and $0.2 \mathrm{~mm}$. The fine silt is found in the river estuaries.

The 1D model RIVTOX of river dynamics and radionuclide transport was adapted to the $\mathrm{Ob}$ ' River path from Mayak and SCC and to the Yenisey River from MCC (see Figure 1). The river network was subdivided into a set of branches in compliance with the location of observation points and the main tributaries. The parameters of water cross-sections for observation points were used. The monthly tributary discharge values for 1949-1995 were used to simulate river hydraulics. The data on 
release from the radionuclide sources were collected in frame of RADARC project [1]. The THREETOX was customised for the Ob' and Yenisey estuaries using digitised navigational maps of estuaries. The horizontal grid resolution is $8 \times 6 \mathrm{~km}$ in the Ob' and $3 \mathrm{~km}$ in the Yenisey. The 6hr fields of wind, air temperature, precipitation, humidity and cloudiness were used from NCEP reanalysis for the period 1949-1995. Daily mean discharges of rivers, suspended sediment and radionuclide concentrations were calculated by the RIVTOX model. In the estuary mouth, the temperature, salinity and velocity distributions and sea level computed by the Kara Sea model [1] were used in the estuary model as outer boundary conditions. The simulations of the period 1949-1994 were carried out for the Ob’ River and period 1959-1994 for the Yenisey River. Distribution coefficients $K_{d}^{w}$ and $K_{d}^{b}$ were $0.25 \mathrm{~m}^{3} \mathrm{~kg}^{-1}$ and $0.8 \mathrm{~m}^{3} \mathrm{~kg}^{-1}$ for ${ }^{90} \mathrm{Sr}$ and $3 \mathrm{~m}^{3} \mathrm{~kg}^{-1}$ and $15 \mathrm{~m}^{3} \mathrm{~kg}^{-1}$ for ${ }^{137} \mathrm{Cs}$, respectively. The values of exchange rate were $a_{12}^{w}=1$ day $^{-1}, a_{12}^{b}=(100 \text { day })^{-1}$ for ${ }^{90} \mathrm{Sr}$ and $a_{12}^{w}=1$ day ${ }^{-1}, a_{12}^{b}=(333 \text { day })^{-1}$ for ${ }^{137}$ Cs, respectively.

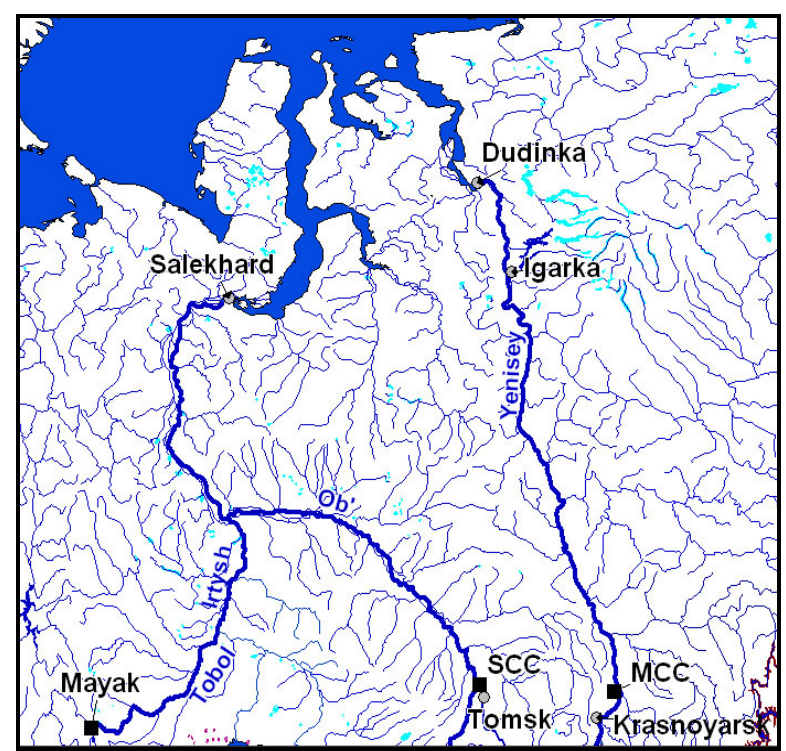

Figure 1. Pathways of the radionuclide contamination from Mayak, SCC and MCC of the Kara Sea.

To study the impact from global warming on radioactive spreading a set of runs were carried out with realistic scenarios of potential release and meteorological and hydrological data from the climate simulations with use of ECHAM3 model of general circulation for scenario of doubling of $\mathrm{CO}_{2}$. ECHAM3 model provide the river discharges in the large river mouths. The statistical procedure of reconstruction of river discharge in the tributaries using discharge in the river and climate correlations for river branches was used.

\section{RESULTS OF SIMULATIONS}

The model chain was validated against the available data on river discharge, suspended sediment and radionuclide concentration, temperature, salinity and ice distribution in the estuaries. In Figures 2-3 the surface fields of temperature and salinity in the Ob’ Bay and Yenisey Gulf in September 1994 are presented. The computed temperature and salinity agree well with the survey data from KAREX-94. It should be pointed that in relatively short and deep Yenisey Gulf the effect of stratification are more important than in the shallow Ob' Bay where salt wedge entered inside the Ob' Bay at low discharge. In Figures 4-7 the contribution of Mayak in ${ }^{90} \mathrm{Sr}$ and ${ }^{137} \mathrm{Cs}$ contamination of the Ob' river system and the Kara Sea is presented. In Figure 4 the yearly averaged fluxes of ${ }^{90} \mathrm{Sr}$ and ${ }^{137} \mathrm{Cs}$ from Mayak and Ob’ Bay mouth to the Kara Sea are given. These figures show that after strong initial contamination in 
early $50^{\text {th }}$ the sediments in the Ob' River were sources for secondary contamination of river and estuary. The huge $\mathrm{Ob}$ ' River estuary served as reservoir of radionuclides with large residence time. Around $15 \%$ and $79 \%$ released in $1949-1956{ }^{137} \mathrm{Cs}$ and ${ }^{90} \mathrm{Sr}$, respectively, reached the $\mathrm{Ob}$ ' delta whereas for period $1949-196861 \%$ and $82 \%$ released ${ }^{137} \mathrm{Cs}$ and ${ }^{90} \mathrm{Sr}$, respectively, entered in the estuary. However, only $1.3 \%$ and $64 \%$ released in $1949-1956{ }^{137} \mathrm{Cs}$ and ${ }^{90} \mathrm{Sr}$, respectively, reached the Kara Sea whereas for period $1949-196813 \%$ and $76 \%$ released ${ }^{137} \mathrm{Cs}$ and ${ }^{90} \mathrm{Sr}$, respectively, entered in the sea. In Figure 5 the calculations are compared with ${ }^{90} \mathrm{Sr}$ measurements in Musliumovo $(27 \mathrm{~km}$ from Mayak along the Techa River) and Pershinskoe (162 km from Mayak along the Techa River). As seen from figure the RIVTOX model reproduces observed in Musliumovo and Pershinskoe concentrations [4] quite well. The comparison of ${ }^{90} \mathrm{Sr}$ measured [5] and calculated concentration in Salekhard in Figure 6a showed that after 1960 Mayak input in the river contamination was much less global fallout. The observed ${ }^{90} \mathrm{Sr}$ concentration in the Lena River [5] is shown in figure as rough estimate of global fallout effect. The "reconstructed" concentration in Salekhard is represented in Fig. 3a as sum of calculated and measured in Lena River. It is more closely to observed curve but observed level of contamination is higher that can be explained by difference between $\mathrm{Ob}$ ' and Lena river basins.
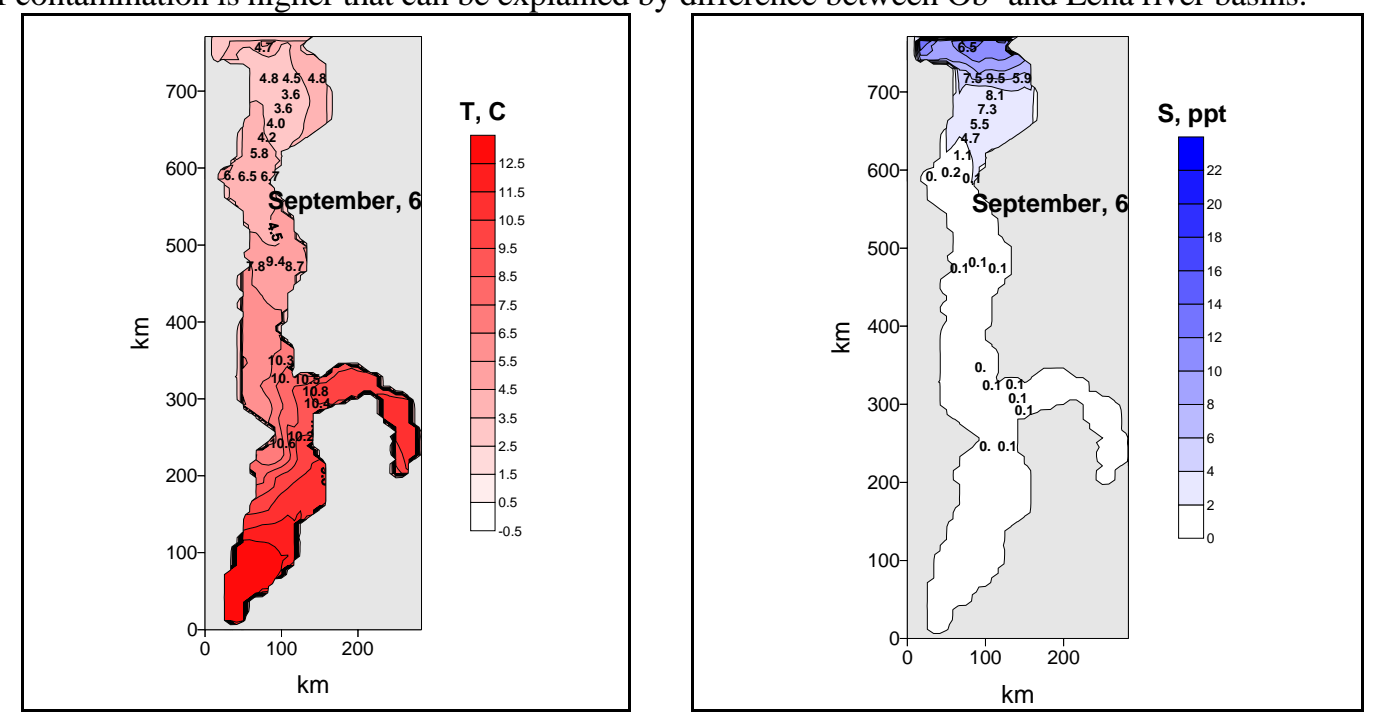

Figure 2. The computed surface fields of temperature (a) and salinity (b) vs survey data KAREX-94 in the Ob’ Bay.
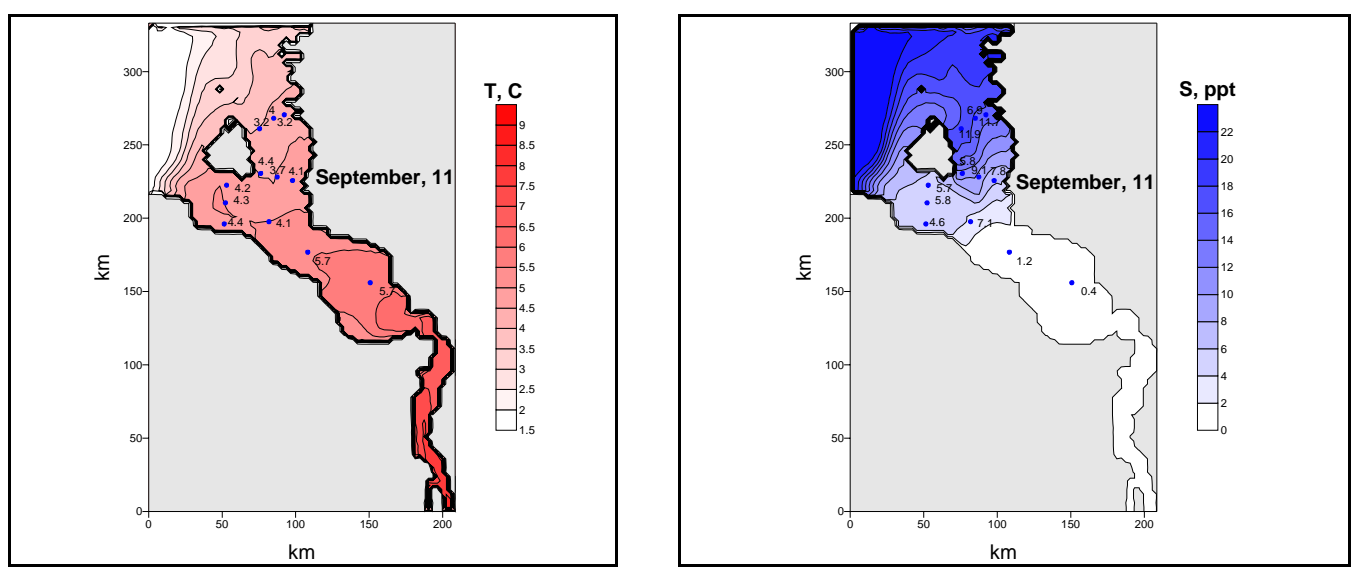

Figure 3. The computed surface fields of temperature (a) and salinity (b) vs survey data KAREX-94 in the Yenisey Gulf. 
The measured [5] and simulated concentration in Igarka (Yenisey River) is presented in Figure 6b. This figure shows that input of MCC in Yenisey contamination in $70^{\text {th }}-90^{\text {th }}$ was much less than global fallout estimated using Lena River data. While, simulations and measurements showed that MCC was main source of ${ }^{137} \mathrm{Cs}$ transported by Yenisey River waters.

The surface distribution of ${ }^{90} \mathrm{Sr}$ in solute and concentration of ${ }^{90} \mathrm{Sr}$ in the bottom in the Ob' Bay in the summer of 1954 are presented in Figure 7 . This time corresponds to the period in 1953-1954 of maximal contamination of Ob’ Bay that exceed $13000 \mathrm{~Bq} \mathrm{~m}^{3}$ in solute in the Ob' delta. The figure show also clean water of Taz River that dilutes Ob' water.

To access radionuclide flux to the Kara Sea for scenarios of potentially possible accidents at Mayak, SCC and MCC a number of simulations was carried out for different seasons of XX century and scenarios of global warming in XXI century. Three scenarios of accident were considered:

(1) Mayak. This scenario assumes a sudden and uncontrollable break of the dam of reservoir-11 and instantaneous release of $296 \mathrm{TBq}$ of ${ }^{90} \mathrm{Sr}$.
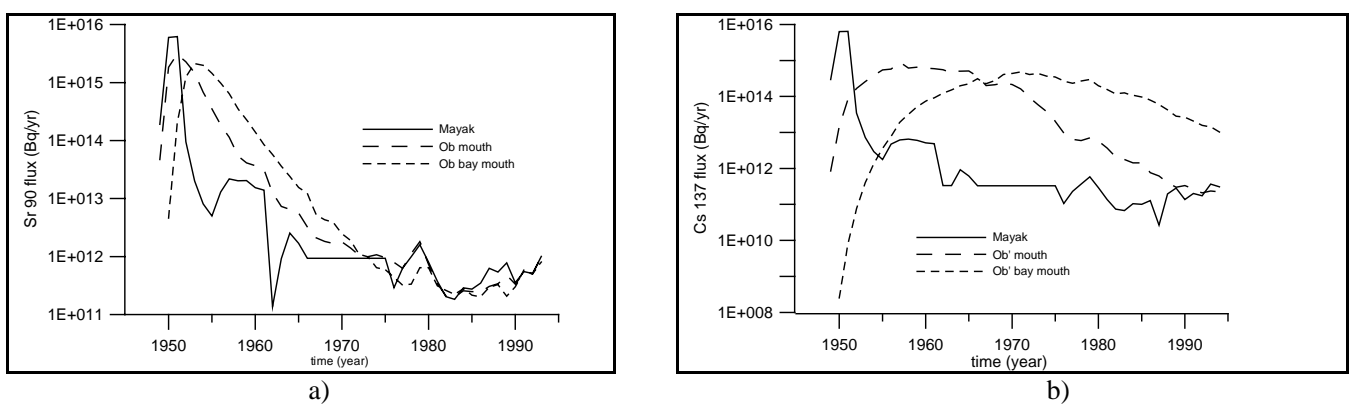

Figure 4. Simulated fluxes of ${ }^{90} \mathrm{Sr}$ (a) and ${ }^{137} \mathrm{Cs}$ (b) from Mayak through Ob’ River and Bay in 1949-1994.
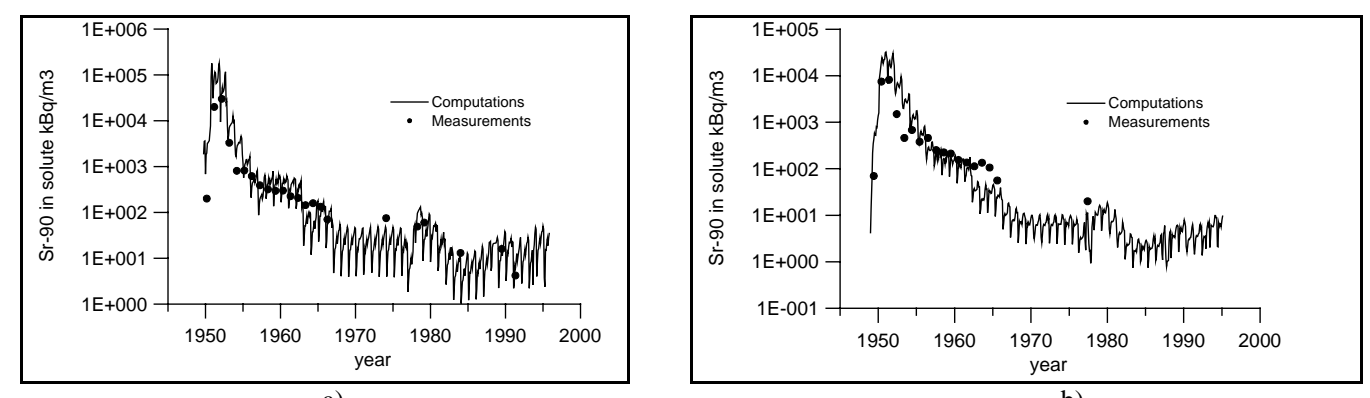

a)

Figure 5. Simulated and observed [5] ${ }^{90}$ Sr concentration in solute in Musliumovo (a) and Pershinskoe (b).

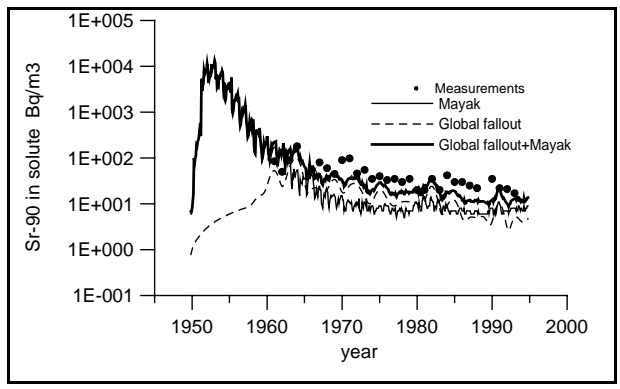

a)

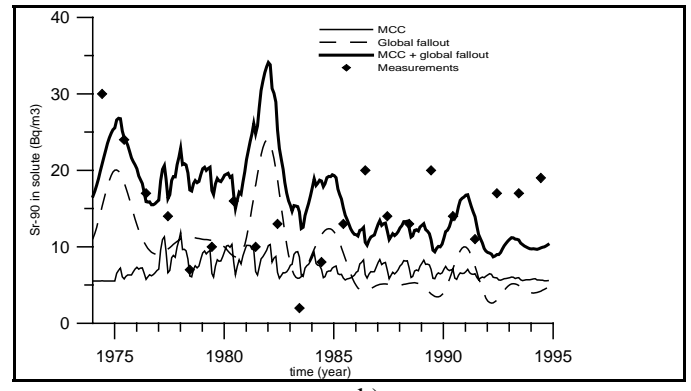

b)

Figure 6. Simulated and observed [5] ${ }^{90} \mathrm{Sr}$ concentration in solute in Salekhard (a) and Igarka 9 (b). 
(2) SCC. The scenario assumes instantaneous release of $37 \mathrm{TBq}$ of ${ }^{137} \mathrm{Cs}$ from one of ponds of SCC to Tom River .

(3) MCC. Scenario with break-down of the holding ponds No 365 and 366 dam was considered. This scenario assumes a sudden and uncontrollable break of the dam of ponds No 365 and 366 that results in instantaneous release of $0.31 \mathrm{TBq}{ }^{137} \mathrm{Cs}$ in solute and $42 \mathrm{TBq}{ }^{137} \mathrm{Cs}$ in sediments. A number of relevant simulations for these scenarios was carried out for "normal climate" conditions (1967) and for scenario with global warming (2084). The simulations did not showed essential influence climate differences on the radionuclide transport by the river system because natural river discharge variability is the same order as the induced by climate change. Climate change can be important in radionuclide transport in the ocean at the cost of change of circulation. In all scenarios maximal concentration of the radionuclides in estuaries do not exceed $10^{0}-10^{2} \mathrm{~Bq} \mathrm{~m}{ }^{-3}$.

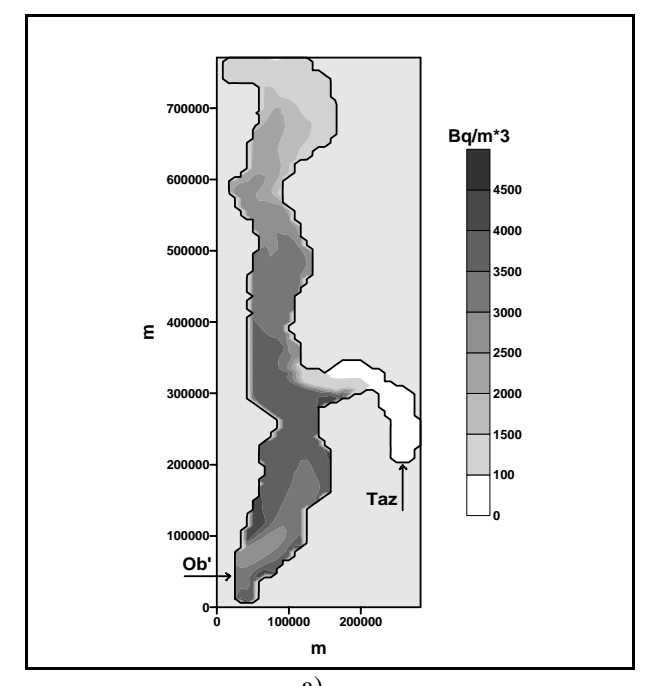

a)

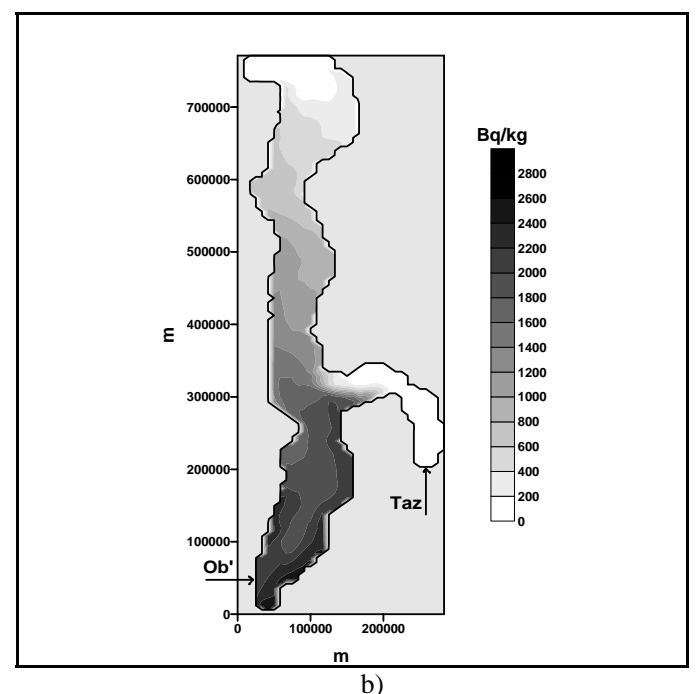

b)

Figure 7. The simulated surface distribution of ${ }^{90} \mathrm{Sr}$ in solute and concentration of ${ }^{90} \mathrm{Sr}$ in the bottom in the $\mathrm{Ob}^{\text {, }}$ Bay in the summer 1954.

\section{CONCLUSIONS}

A linked chain of 1D river model and 3D model of stratified estuary was was adapted to the Ob' River path from Mayak and SCC and to the Yenisey River from MCC.The model chain was validated against the available data on river discharge, suspended sediment and radionuclide concentration, temperature, salinity and ice distribution in the estuaries. The results of multi-year simulation of the water dynamics and radionuclide transport in the Ob' and Yenisey rivers and estuaries showed ability of the developed model chain to reproduce radionuclide fluxes from terrestrial sources. The developed model chain can be used for assessment of the radionuclide spreading from inland sources.

\section{Acknowledgments}

This paper is result of co-operation under by EU INCO-COPERNICUS project RADARC (Contract ICA-CT-2000-10037) and project INTAS - 1997-31278. The close co-operation and helpful discussions with O. Johannessen, L. Pettersson (NERSC, Norway), S. Nielsen (RISO, Denmark), A. Stepanov (KRI, Russia) and I. Neelov (NIERSC, Russia) are highly appreciated. 


\section{References}

[1] Johannesen, O. M. et al., "Simulation for potential radioactive spreading in the 21 century from rivers and external sources in the Russian arctic coastal zone-RADARC", 5th Int. Conf. on Env. Radioactivity in the Arctic \& Antarctic., St. Petersburg, Russia, 15-17 June 2002, P. Strand, T. Jølle and Å. Sand Eds. (NRPA, Norway, 2002) pp. 53-57.

[2] Zheleznyak M. et al., Sci. Tot. Env. 112 (1992) pp. 89-114.

[3] Margvelashvili N., Maderich V. and Zheleznyak M., Rad. Prot. Dosimetry, 73 (1997) pp.177-180.

[4] Kryshev, I.I. (Ed.) Environmental Risk Analysis for the Ural Radioactive Pattern. (Nuclear Society, Moscow, 1997) pp. 1-214.

[5] Chumichov V. B., " Sr-90 discharge with main rivers of Russia into the Atlantic Ocean during 1961-1990", Environmental Radioactivity in the Arctic, P. Strand and A. Cooke Eds. (Norwegian Radiation Protection, Osteras, Norway, 1995) pp. 79-83. 